IZA DP No. 6131

Can Money Change Who We Are?

Estimating the Effects of Unearned Income on Measures of Incentive-Enhancing Personality

Nattavudh Powdthavee

Christopher J. Boyce

Alex M. Wood

November 2011 


\title{
Can Money Change Who We Are? Estimating the Effects of \\ Unearned Income on Measures of Incentive-Enhancing Personality Traits
}

\author{
Nattavudh Powdthavee \\ Nanyang Technological University \\ and IZA
}

Christopher J. Boyce

University of Manchester

Alex M. Wood

University of Manchester

\section{Discussion Paper No. 6131 \\ November 2011}

\author{
IZA \\ P.O. Box 7240 \\ 53072 Bonn \\ Germany \\ Phone: +49-228-3894-0 \\ Fax: +49-228-3894-180 \\ E-mail: iza@iza.org
}

\begin{abstract}
Any opinions expressed here are those of the author(s) and not those of IZA. Research published in this series may include views on policy, but the institute itself takes no institutional policy positions.

The Institute for the Study of Labor (IZA) in Bonn is a local and virtual international research center and a place of communication between science, politics and business. IZA is an independent nonprofit organization supported by Deutsche Post Foundation. The center is associated with the University of Bonn and offers a stimulating research environment through its international network, workshops and conferences, data service, project support, research visits and doctoral program. IZA engages in (i) original and internationally competitive research in all fields of labor economics, (ii) development of policy concepts, and (iii) dissemination of research results and concepts to the interested public.
\end{abstract}

IZA Discussion Papers often represent preliminary work and are circulated to encourage discussion. Citation of such a paper should account for its provisional character. A revised version may be available directly from the author. 


\section{ABSTRACT \\ Can Money Change Who We Are? \\ Estimating the Effects of Unearned Income on Measures of Incentive-Enhancing Personality Traits*}

The importance of noncognitive childhood skills in predicting higher wages is well documented in economics. This paper studies the reverse. Using surveys of lottery winners, we analyze the effects of unearned income on the Big Five personality traits. After correcting for potential endogeneity problems from prize sizes, we find that unearned income improves traits that predict pro-social and cooperative behaviors, preferences for social contact, empathy, and gregariousness, and reduces individuals' tendency toward negative emotional states: known in economics literature as incentive-enhancing personality traits. Our results support the possibility of scope for later interventions to improve the personality traits of adults.

JEL Classification: D3, J24

Keywords: noncognitive skills, personality traits, lottery winners, instrumental variables, unearned income

Corresponding author:

Nattavudh Powdthavee

Division of Economics

School of Humanities \& Social Sciences

Nanyang Technological University

14 Nanyang Drive

Singapore 637332

E-mail: n.powdthavee@ntu.edu.sg

\footnotetext{
* We wish to thank Jan Kiviet, Yohannes Riyanto, Guiying Wu, Emma Hoyle, and participants at the NTU seminar. The British Household Panel Survey data were made available through the UK Data Archive, and the German Socio-Economic Panel were made available through DIW Berlin. Neither the original collectors of the data nor the Archive bear any responsibility for the analyses or interpretations presented here.
} 
A large amount of published work in economics argues that any intervention to improve noncognitive skills (otherwise known as incentive-enhancing personality traits) must be done at the very early stage of a child's development rather than later in the lifecycle. One explanation for this is the early finding in psychology that personality traits develop only in childhood before maturity and "set like plaster" as soon as individuals enter adulthood. By contrast, recent papers in psychology argue that personality traits are not fixed across the lifecycle and that they tend to change in accordance with fluctuations in life experiences and social environments, which means that there should always be scope for later intervention potentially to improve adults' noncognitive abilities. Such an apparent disparity between the findings and conclusions of two schools of thought is scientifically unattractive.

Our paper focuses on a particular positive event - an increase in individual's unearned income - to gauge whether noncognitive traits can be influenced by such a change. We present econometric evidence consistent with previous literature that uses lottery wins to provide an exogenous variation of income to study the causal effect of income on measures of the well-known Big Five personality traits: agreeableness, extraversion, conscientiousness, neuroticism, and openness. In many cases, we find important effects that run from unearned income to three out of the five dimensions of personality, all of which are considered to be traits highly valued by employers. Our results suggest that economists may need to revise their standard conceptual apparatus and accept that there may after all be scope for later intervention to improve the personality traits of adults.

\section{Background}

Our understanding of what constitutes labor market "skills" is changing. In recent years, there has been a significant increase in the number of studies written almost exclusively on the importance of noncognitive skills, as opposed to cognitive skills, on the probability of labor market successes. The overall finding is clear: There is favorable evidence for the development and acquisition of noncognitive abilities in the labor market. For example, Barrick and Mount (1991), Salgado (1997), and Bowles et al. (2001a) find that measures of noncognitive skills explain a significant variation in employees' effort and productivity at the workplace. Using the National Longitudinal Survey of Youth in the U.S.A., Heckman et al. (2006) show that noncognitive traits such as self-esteem and locus of control significantly influence pay for male and female workers; they find that a move from the 25 th to the 75 th 
percentile of the noncognitive skill distribution is associated with a wage increase of approximately 10 percentage points for men and more than 30 percentage points for women. More recently, Heineck (2011) uses the British Household Panel Survey to demonstrate a positive correlation between wages and individuals' openness to experiences, as well as a negative relationship between wages and the degree to which the individual is insecure, anxious, and depressive. Qualitatively similar results can also be obtained for the U.S.A. (Groves, 2005), the Netherlands (Nyhus \& Pons, 2005), and Russia (Semykina \& Linz, 2007). ${ }^{2}$ In short, there is bounty of evidence in the economics and psychology literature to suggest that noncognitive skills are important predictors of several successful labor market outcomes.

In an attempt to explain the phenomenon, Bowles et al. (2001a) attribute the link between noncognitive skills and wages to the "incentive-enhancing" model, which specifies that certain noncognitive characteristics or traits enable employers to elicit effort at a lower cost, i.e., individuals with high levels of creativity and self-control may tend to react differently to incentives set by employers aimed at increasing effort among employees. If these traits are realized by employers, then employees with the incentive-enhancing attributes are likely to be rewarded through wage setting. In other words, noncognitive traits may be rewarded in the labor market independently of traditional indicators of human capital and job-specific variables, provided that they foster individuals' degree of future orientation and personal efficacy as well as increase their net marginal utility derived from work over effort (Bowles et al., 2001; see also Nyhus \& Pons, 2005).

How, then, are these noncognitive attributes measured and defined? Is there a universally accepted measure of noncognitive skills? While cognitive skills are usually associated with intelligence and the ability to solve abstract problems, both of which can be measured objectively through IQ tests and standard tests in reading, math, and science literacy, noncognitive skills are considerably more subjective in nature and can be elicited through self-completed surveys (Brunello \& Schlotter, 2011). According to Nyhus and Pons

\footnotetext{
${ }^{2}$ For a comprehensive review of the literature on the benefits of noncognitive skills on various economic outcomes, see Bowles et al. (2001b), Borghans et al. (2008), and Brunello and Schlotter (2011). Moreover, the potential benefits of noncognitive skills in economics are not limited only to labor market outcomes. Within subjective well-being research it has also been shown that noncognitive skills play an important role in the impact that certain life events have on well-being. For example, individuals who are more conscientious tend to experience larger drops in life satisfaction following unemployment (Boyce et al., 2010a), and a willingness to help others and act in accordance with others may help individuals fully adapt psychologically following a disability (Boyce \& Wood, 2011b). Personality traits also help moderate the size of the association between income and self-reported happiness (see, e.g., Clark et al., 2005; Boyce \& Wood, 2011a).
} 
(2005), noncognitive skills are personality traits that are weakly correlated with intelligence, and while there are many sub-measures of these traits, psychologists tend to broadly categorize them into five dimensions of personality traits: agreeableness, conscientiousness, extraversion, neuroticism, and openness. Agreeableness measures our tendency to be pleasant, warm, and agreeable in social situations, as well as our degree of willingness to act in accordance with other people's interests. It is also the key trait for predicting prosocial, cooperative, and helping behaviors (Penner et al., 1995). Conscientiousness reflects our preferences for following rules and schedules as well as our attitude to being hardworking, organized, and dependable. Extraversion measures our needs for external stimuli and preferences for human contacts, empathy, gregariousness, assertiveness, and the wish to inspire people. Extroverted individuals are more likely to be facilitators in groups and tend to be significantly happier than others on average. Neuroticism represents our tendency to experience negative emotional states such as anxiety, anger, guiltiness, and depressive moods. Empirically it has been found to be strongly related to workplace absenteeism, lower productivity, increased use of health care services (for physical and mental complaints), and increased unemployment. Openness (otherwise known as autonomy) measures our preferences for taking initiatives and control as well as our degree of active imagination, aesthetic, sensitivity, and intellectual curiosity. ${ }^{3}$

Economists are not only concerned with how noncognitive skills are measured, but also with how and when these skills are developed and produced. According to Caneiro and Heckman (2003) and Cunha and Heckman (2007), noncognitive skills measured in adulthood are predominantly shaped very early on by family and school inputs, and any intervention to foster the development of noncognitive skills must be carried out during school years or as early as possible for it to be effective. These strong preferences for an "early intervention" rather than later intervention are justified by Heckman and colleagues' use of a psychological theory called "set like plaster," which essentially states that personality traits continue to develop throughout childhood before setting like plaster when individuals reach adulthood (McCrae \& Costa, 1999). If this theory is true, then it effectively means that there would be no scope for later intervention to improve personality traits in adulthood (Brunello \& Schlotter, 2011).

\footnotetext{
${ }^{3}$ The Big Five personality traits are arguably better measures of noncognitive skills than the Rotter scale measure of self-control and the Rosenberg Scale measure of self-worth used in Heckman et al. (2006), considering that the former cover more dimensions of individuals' noncognitive traits than the latter.
} 
There is, however, some evidence, primarily from the psychology literature, which suggests that personality traits change systematically with life events even after the age of 30 . For example, conscientiousness and agreeableness increase throughout early and middle adulthood at varying rates, whereas neuroticism tends to decline among women but does not change for men (Agronick \& Duncan, 1998; Srivastava et al., 2003; Roberts et al., 2006). Brunello and Schlotter (2011) find that individuals' locus of control - one of the characteristics of openness - improve with the number of hours spent in workplace training. Hence, these studies present evidence that rejects the "set like plaster" theory and suggest that personality traits are driven by context and that they can be influenced by changes in life events such as marriage, unemployment, and disability experienced during adulthood (e.g., Haan et al., 1986; Hogan, 1996; Specht et al., 2011).

Yet despite the counter-examples of the "set like plaster" theory in the economics and psychology literature, there is still no persuasive reason to believe that life events and later interventions can cause changes in personality traits in adulthood. ${ }^{4}$ Since much of these studies are carried out at cross section without any identification strategy, the results can be interpreted only with care. The reason for this is simple: There are two main sources of bias associated with estimating the effect of life circumstances on personality traits. The first is that causality may also run in reverse from personality traits to different life experiences; e.g., individuals who are more conscientious and open to experience may select themselves into higher-paying occupations and/or more workplace training compared to others (see, e.g., Winkelmann \& Winkelmann, 2008). Moreover, there may be omitted heterogeneity that influences both life events and noncognitive outcomes, which could lead to an inconsistent estimation of the coefficients of interest.

Our aim in this paper is to argue that changes in life circumstances can cause our personality traits to change in a way that is qualitatively important and statistically significant. We suggest that income is a potential instrument for changes in noncognitive abilities in adulthood. With respect to the Big Five personality traits, one could imagine that an increase in income allows individuals to be relatively freer from financial obligations and therefore make them more gregarious and open to new experiences. However, since income is likely to be endogenous in the personality trait equations - i.e., people who have higher levels of autonomy will tend to earn more in the labor market (Nyhus \& Pons, 2005) - we

\footnotetext{
${ }^{4}$ The same argument applies for children, although evidence on the subsequent effect on future economic behaviors of early intervention in noncognitive skills is much more compelling than for adults.
} 
utilize data from lottery wins and focus our attention on analyzing the effect of unearned income on each of the Big Five personality traits, which we take as proxies for noncognitive skills. After correcting for the potential bias associated with the lottery data, we document evidence that, among lottery winners, an increase in unearned income causes people to become more agreeable and extroverted as well as less sensitive to negative experiences, all of which are classified by Nyhus and Pons (2005) as incentive-enhancing characteristics and highly valued by employers (see also Bowles et al., 2001a). Nonetheless, we find, as anticipated, no evidence of a statistically important unearned income effect on openness to experiences.

Our study follows in a different way the same interests and testing strategy as Sacerdote (1996), Imbens et al (2001), Gardner and Oswald (2007), and Apouey and Clark (2009). It differs from studies that use instrumental variables (IV) to measure for earned incomes (e.g., Luttmer, 2005; Powdthavee, 2010) and changes in the institutional system (Frijters et al., 2004) in an attempt to identify the causal effect of income on subjective data.

\section{II.Data}

The primary data set in this study comes from the British Household Panel Survey (BHPS). The BHPS contains a nationally representative sample of British households, covering over 10,000 randomly selected individuals from more than 5,000 households. The survey has been conducted between September and Christmas of each year since 1991 (Taylor et al., 2002).

The current study draws on two sets of survey questions in the BHPS. The first set asks individuals in every wave since 1997 to report the types and amounts of windfalls they have received in the last 12 months. The types include money from a life insurance policy, lump-sum pension, personal accident claim, redundancy payment, employment bonus, inheritance/bequest, and win on football (soccer) pools/national lottery. For the purpose of analyzing the causal impact of income on personality traits, we focus our attention only on the amount of win on football pools/national lottery. As half of the British population play the national lottery, this form of winning windfalls swamps all other forms, and for simplicity we refer later merely to "lottery winners" (Wardle et al., 2007). However, it is worth noting here that there are two main limitations associated with the lottery variable in the BHPS. First, we observe only lottery winners but we do not have any information on those who did not play 
and those who played and did not win. Second, we do not observe how much people spend on the lottery and how frequently people play the lottery, which makes it impossible to establish whether the size of the lottery win is significantly correlated with the individual's rate of participation in the national lottery. We shall address these two problems later through Hausman tests of endogeneity and an IV approach.

The second set of questions, which appear only in Wave 15 of the BHPS, is used to elicit the respondents' Big Five personality traits (Nyhus \& Pons, 2007). Individuals are asked to self-report on a 7-point scale from 1 (Does not apply) to 7 (Applies perfectly) the extent to which the following statements apply to them:

1. I see myself as someone who is sometimes rude to others (Agreeableness)

2. I see myself as someone who does a thorough job (Conscientiousness)

3. I see myself as someone who is talkative (Extraversion)

4. I see myself as someone who worries a lot (Neuroticism)

5. I see myself as someone who is original and comes up with new ideas (Openness)

6. I see myself as someone who has a forgiving nature (Agreeableness)

7. I see myself as someone who tends to be lazy (Conscientiousness)

8. I see myself as someone who is outgoing and sociable (Extraversion)

9. I see myself as someone who gets nervous easily (Neuroticism)

10. I see myself as someone who values artistic, aesthetic experiences (Openness)

11. I see myself as someone who is considerate and kind to almost everyone (Agreeableness)

12. I see myself as someone who does things efficiently (Conscientiousness)

13. I see myself as someone who is reserved (Extraversion)

14. I see myself as someone who is relaxed, handles stress well (Neuroticism)

15. I see myself as someone who has an active imagination (Openness)

Aggregating the scores from Q1, Q6, and Q11 gives an index for Agreeableness. The sum of Q2, inversed Q7, and Q12 produces an index for Conscientiousness. The sum of Q3, Q8, and inversed Q13 yields an index for Extraversion. Adding Q4, Q9, and the inversed score of Q14 yields an index for Neuroticism, and an index for Openness can be constructed by aggregating the scores from Q5, Q10, and Q15. 
We utilize data from Wave 15 of the BHPS (and Waves 14 and 16 for data on lottery wins at $t-1$ and $t+1)$. In Wave 15 , there are 1,053 lottery winners; of those, 58 percent are men. Approximately 78 percent $(\mathrm{N}=822)$ are winners who received small wins of between $£ 1$ and $£ 99$ (or between $\$ 1.5$ and $\$ 150$ ), with the remainder, i.e., 22 percent $(\mathrm{N}=231)$, winners who received medium-sized wins of between $£ 100$ and $£ 185,000$ (that is, up to approximately $\$ 280,000)$. Descriptive statistics and the distribution of lottery wins (in natural log form) can be found in Table 1 and Figure 1 respectively.

\section{III.Analytical strategy}

\section{A. Identification problem}

According to contextual theory of personality, in which personality can be influenced by changes in life events and social environments - i.e., personality traits are not predetermined - and evidence that people with different personalities may select themselves into jobs of various pays (see, e.g., Heineck, 2011), the relationship between income (in a natural log form) and a selected personality trait can be represented by a pair of simultaneous equations

$$
P_{i}=\alpha_{1}+\alpha_{2} \ln Y_{i}+\lambda X_{i}^{\prime}+e_{i}
$$

$$
\ln Y_{i}=\beta_{1}+\beta_{2} P_{i}+\delta X_{i}^{\prime}+\varepsilon_{i}
$$

where $P_{i}$ is a standardized personality score assigned to individual $i$; $\ln Y_{i}$ is a natural $\log$ of individual $i$ 's real personal income; $X_{i}^{\prime}$ is a vector of the exogenous variables; and both $e_{i}$ and $\varepsilon_{i}$ are the error terms. Equations (1) and (2) imply that personality and personal income are jointly determined, i.e., endogenous. The reduced forms of (1) and (2) are given by

$$
\begin{aligned}
& P_{i}=\Pi_{1}+\Pi_{2} X_{i}^{\prime}+v_{i}, \\
& \ln Y_{i}=\Lambda_{1}+\Lambda_{2} X_{i}^{\prime}+v_{i},
\end{aligned}
$$

where the parameters are defined as:

$$
\Pi_{1}=\frac{\alpha_{1}+\alpha_{2} \beta_{1}}{1-\alpha_{2} \beta_{2}}, \Pi_{2}=\frac{\lambda+\alpha_{2} \delta}{1-\alpha_{2} \beta_{2}}, \Lambda_{1}=\frac{\beta_{1}+\beta_{2} \alpha_{1}}{1-\alpha_{2} \beta_{2}}, \Lambda_{2}=\frac{\delta+\beta_{2} \lambda}{1-\alpha_{2} \beta_{2}}
$$


with the error terms: $v_{i}=\frac{\alpha_{2} \varepsilon_{i}+e_{i}}{1-\alpha_{2} \beta_{2}}$ and $v_{i}=\frac{\beta_{2} e_{i}+\varepsilon_{i}}{1-\alpha_{2} \beta_{2}}$. Assuming that $X_{i}^{\prime}$ is uncorrelated with $v_{i}$, we find that $E\left(\ln Y_{i} e_{i}\right)=\frac{\beta_{2}}{1-\alpha_{2} \beta_{2}} E\left(e_{i} e_{i}\right)$. Provided that $\left(1-\alpha_{2} \beta_{2}\right)>0$, it can be concluded that $E\left(\ln Y_{i} e_{i}\right) \neq 0$ and that attempts to estimate the effect of income on personality (or $\alpha_{2}$ ) will be hampered by simultaneity bias.

\section{B. Lottery wins and the instrumental variables approach}

The simultaneity bias can be solved if there is a valid instrument, $Z$, that is strongly correlated with income but has no direct influences on the respondent's personality traits. However, creating a valid instrument for income is not easy. Potential instruments such as spouse's income and lagged personal income are unsuitable as they are likely to be strongly correlated with the observed and unobserved characteristics that also determine the respondent's personality traits, e.g., the fact that "like" tends to marry "like" in positive assortative mating couples (see, e.g., Powdthavee, 2009).

To address the simultaneity bias, we first attempt to minimize the size of the correlation between our endogenous regressor of interest and the error term by replacing log of personal income in Eq. (1) with log of real lottery win (in 2005 prices), $\ln L_{i}$. Since the size of a lottery win is likely to be randomized among winners, it is almost certain that $\operatorname{cov}\left(\ln Y_{i} e_{i}\right) \geq \operatorname{cov}\left(\ln L_{i} e_{i}\right)$. Provided that $\operatorname{cov}\left(\ln L_{i} e_{i}\right)=0$, we can readily estimate the effect of income on personality trait without having to resort to an IV approach to correct for the endogeneity bias.

Yet the assumption that the size of lottery win is randomized may be too strong in our case, considering that the lottery win itself is badly measured in the BHPS, i.e., we have no information on how frequently people played the lottery and how much money was spent on the lottery tickets. In other words, there is a legitimate reason to believe that $\operatorname{cov}\left(\ln L_{i} e_{i}\right) \neq 0$ because the (total) size of the lottery win may be correlated with how often people participate in the lottery, which in turn is likely to be correlated with other sources of incomes and some observed and unobserved characteristics. This is reflected in evidence of a nonzero and statistically significant correlation between the size of the lottery win and certain socio- 
economic characteristics (or the right-hand-side variables) that are also likely to be correlated with personality traits. For instance, the size of the lottery win is shown to be strongly correlated with household income, having a university degree, and marital statuses (Apouey \& Clark, 2009; see also Georgellis et al., 2008). Without the ability to control for how often people play the lottery and how much people spend on it, our ordinary least-squares (OLS) estimates will be biased (and likely to be biased toward zero because of the measurement error). Therefore, the presence of an endogeneity bias in the lottery variable implies that an IV, Z, which correlates with the amount won but is otherwise uncorrelated with the error term, is still required in order to identify the causal effect of lottery win (or income) on personality traits.

A potential IV for the amount of win today is the amount won in the previous year. The exclusion restriction assumption here is that some of the amount won will be used to purchase future lottery tickets; the larger the win, the more resources will be allocated to purchasing future tickets, which in turn raises the probability of future wins (although the relationship between amount won and future purchases and wins may be nonlinear). However, it can be argued that previous wins do not have direct influences on personality traits beyond their impacts on the win received today. Equivalently, we could say that personality traits have no significant influences on future lottery wins, conditioning on the individual's current unearned income from the lottery win.

To illustrate this point, we introduce in Table 2 the time subscript, $t$, into the regression equation and estimate the following equation on all lottery winners at $t+1$ :

$$
\ln L_{i t+1}=\gamma_{1}+\gamma_{2} P_{i t}+\gamma_{3} L_{i t}+\gamma_{4} L_{i t}^{2}+\gamma_{5} X_{i t}+\xi_{i t}
$$

where $\ln L_{i t+1}$ is a natural $\log$ of lottery win at $t+1$, and $L_{i t}$ and $L_{i t}^{2}$ are lottery win at $t$ and its square, respectively. ${ }^{5}$ Nonwinners in $t$ are assigned the value 0 in both $L_{i t}$ and $L_{i t}^{2}$ simply because not all winners in $t+1$ have won the lottery in $t$; of those who had won in $t+1$, approximately 50 percent had not won in $t$. The inclusion of nonwinners in $t$ is justified by the fact that all of these individuals went on to win a lottery at $t+1$ and can therefore be considered as the "playing" type who, even if they had not won in $t$, are likely to share similar

\footnotetext{
${ }^{5}$ Equivalently, we could also run a regression model with the size of the lottery win at $t$ as the dependent variable and with all explanatory variables, including personality traits, measured at $t-1$. However, given that we observe only one year of personality traits but multiple years for lottery wins, only Eq. (6) can be run.
} 
characteristics as those who had played and won. Equation (6) thus represents lottery wins at $t+1$ as a function of personality traits and lottery wins as well as a set of exogenous variables - namely age, age-squared, and gender - measured at $t$.

In the first column of Table 2 where $L_{i t}$ and $L_{i t}^{2}$ are restricted to zero, we can see that only one out of the Big Five personality traits measured at $t$ significantly predicts the size of the lottery win at $t$; the estimated coefficient on neuroticism at $t$ is -0.117 , with a welldetermined standard error of 0.0562. However, this coefficient becomes statistically insignificantly different from zero with the inclusion of lottery win and lottery win squared at $t$, which are both statistically significantly at the 1 percent level at predicting the size of the future win. The coefficients on lottery win at $t$ and its square take the positive and negative sign respectively, which implies a nonlinear (concave) relationship between future wins and the amount won today. This indicates that personality traits measured today have no predictive power of future lottery win, conditioning on the size of the win today. For comparative purposes, Columns 3 and 4 re-estimate the first two columns with $\ln Y_{i t+1}$ as the dependent variable and $Y_{i t}$ and $Y_{i t}^{2}$ as additional explanatory variables. From these regression equations, we can see that four out of the Big Five personality traits measured at $t$ are statistically significantly correlated with the size of earned income measured at $t+1$; individuals who possess high levels of conscientiousness and openness as well as low levels of agreeableness and neuroticism are likely to earn significantly more income at $t+1$. Conscientiousness and openness continue to be strongly correlated with future earned incomes even when real personal income at $t$ is controlled for in the estimation, thus highlighting the facts that (i) earned income and personality traits are endogenously determined and (ii) lagged income may not be a valid measure for current income in the personality trait equations. On the other hand, personality traits do not appear to be strongly correlated with future wins beyond their contemporaneous relationships with lottery wins at $t$.

What about the effect of previous lottery win on current personality traits? In other words, could lottery win at $t-1$ have a direct influence on personality variables beyond its impact on the amount win today, which would automatically make past unearned income invalid as a potential instrument for the size of the lottery win at $t$ ? Table 3 tests this by running a regression with each personality trait as dependent variables and current and past lottery wins as independent variables. A test can then be conducted on a null hypothesis that the joint net effects of past lottery win and its square on each personality trait are zero. If the 
null cannot be rejected, it could be concluded that $\operatorname{cov}\left(L_{i t-1} e_{i}\right)=0$ and $\operatorname{cov}\left(L_{i t-1}^{2} e_{i}\right)=0$ and that we may have a set of valid IVs for $\ln L_{i t}$.

While the size of the lottery win at $t$ is strongly related to extraversion (+ve) and neuroticism (-ve) measured in the same survey year, both lottery win at $t-1$ and its square enter all personality trait equations in a statistically insignificant manner. The evidence thus supports our earlier claim that past wins do not have a direct influence on current personality traits beyond their impact on the size of the lottery win today and that $L_{i t-1}$ and $L_{i t-1}^{2}$ are potentially valid IVs.

The next issue of interest is whether there is a statistically important correlation between the $\log$ of lottery win at $t$ and the error term in all of the Big Five personality trait equations, i.e., whether the IV approach is a priori a requirement for all of them. We test this by carrying out a Hausman test for endogeneity and report the results in Table 4 . In the first step, the log of lottery win at $t$ is regressed on all of the exogenous variables, including lottery win at $t-1$ and its square, in order to obtain the predicted residual, $\hat{v}$. This predicted residual is then regressed alongside the log of win at $t$, gender, age, and age-squared in each of the personality trait equations. The null hypothesis is that the estimated coefficient on $\hat{v}$ is equal to zero, i.e., there is a statistically insignificant correlation between the log of lottery win at $t$ and the error term, and that it would be more efficient to estimate the particular personality trait equation using OLS rather than the IV estimator.

In Table 4, we can see that the estimated coefficient on $\hat{v}$ is negative and statistically significant at the 1 percent level in the agreeableness and conscientiousness equations. This indicates that $\operatorname{cov}\left(\ln L_{i t} e_{i t}\right) \neq 0$ in these two equations and that running OLS on these equations will produce biased estimates on the effect of lottery on both agreeableness and conscientiousness. Regarding extraversion, neuroticism, and openness, the Hausman test implies that consistent estimates can be obtained using OLS and that it should be preferred to the less-efficient IV estimator.

More generally, the results in Table 4 provide empirical evidence that the size of the lottery win in the BHPS is not always automatically orthogonal to the error term as previously assumed (see, e.g., Gardner \& Oswald, 2007; Apouey \& Clark, 2009). 
Table 5 lists the first-stage regression estimates. For completeness, we report the estimates for each of the Big Five personality traits even if it may be more efficient to use OLS to estimate the extraversion, neuroticism, and openness equations. As anticipated, the coefficients on lottery win at $t-1$ and its square are statistically significant at the 1 percent level. The excluded instruments are also "strong"; the F-test of joint significance produces an F-statistic of approximately 17, which is higher than the rule of thumb (i.e., F-statistic $=10$ ), and the partial $R^{2}$ is approximately 0.12 . Our overidentifying tests on the surplus instrument also suggest that we have a valid IV (although there is evidence that the null hypothesis can be rejected at the 10 percent level for the conscientiousness equation: Hansen $\mathrm{J}$ statistic $=$ $2.861[0.0907])$.

Table 6 presents OLS and IV estimates. The first panel reports the OLS estimates on the effect of lottery win at $t$ on each of the Big Five personality traits, while the second and third panels report the IV estimates with different sets of control variables, i.e., IV(a) controls only for gender, age, and age-squared, and IV(b) includes additional controls for education, marital statuses, employment statuses, health, log of real personal income, and numbers of children.

According to the OLS estimates, the estimated coefficient on $\ln L_{i t}$ is statistically significant only in the extraversion and neuroticism equations. A 1 percent increase in the lottery win is associated with a 0.05-point increase (in standard deviation) in extraversion and a 0.07-point decrease (also in standard deviation) in neuroticism. Since the Hausman test in Table 4 implies that consistent estimates on the effect of lottery win on personality can be obtained using OLS in the extraversion, neuroticism, and openness equations, we can conclude here that an increase in unearned income leads to an increase in extraversion as well as a reduction in neuroticism.

With respect to the IV estimates, the estimated coefficient on $\ln L_{i t}$ now becomes positive and statistically significant in the agreeableness equation. However, it remains statistically insignificantly different from zero in the conscientiousness equation, which is the only other equation that also suffers from the endogeneity bias. This suggests that the "true" effect of unearned income on agreeableness is in fact positive and statistically important at the 5 percent level: A 1 percent increase in the size of the lottery win leads to a 0.11 -point increase (in standard deviation) in agreeableness. Almost the same estimates are obtained in the agreeableness and conscientiousness equations with more control variables (see IV(b)), 
which implies that it is sufficient simply to control for individuals' gender, age, and agesquared.

In sum, an increase in unearned income affects three out of the Big Five personalities. It makes an individual more gregarious, assertive, and interested in seeking out external stimuli (extraversion). It also makes the person significantly more accommodating and easier to get along with in social situations (agreeableness). It also reduces the person's enduring tendency to experience negative emotional states such as anxiety, anger, and depressive moods (neuroticism). The effects of the lottery win on the three personality traits are also qualitatively important as well as statistically significant; the marginal effects of the lottery win on agreeableness, extraversion, and neuroticism are 11 percent, 5 percent, and 7 percent of the standard deviation respectively.

Table 7 replaces the potentially endogenous variable (i.e., log of lottery win) by a dummy variable with a value of 0 if the lottery win is between $£ 1$ and $£ 999$ (that is, between approximately $\$ 1.5$ and $\$ 1,499)$ and 1 if the win is $£ 1,000$ and over, i.e., $\$ 1,500+$. There are 38 individuals who won $£ 1,000$ or more from the national lottery in 2005 . A test of endogeneity suggests that the "£1,000+ win" is endogenously determined in agreeableness, conscientiousness, and neuroticism equations. Hence, for these three personality trait equations, IV estimates are consistent and thus preferred to the OLS.

Across the panels and columns of Table 7, we observe qualitatively similar results to those of Table 6. The effects are economically meaningful in terms of size: A win of $£ 1,000$ or more is statistically significantly associated with a 0.9 increase of standard deviation in agreeableness, a 0.4 increase of standard deviation in extraversion, a 0.6 point increase of standard deviation in conscientiousness, and a 0.8 point of standard deviation decrease in neuroticism. The effects of unearned income are statistically significant as well as sizeable; the estimated coefficients are statistically significant at the 1 percent level in the agreeableness and extraversion equations, at the 5 percent level in the neuroticism equation, and at the 10 percent level in the conscientiousness equation.

Tables 8 and 9 re-estimate the OLS and IV regression equations by gender and age group. An analysis by gender is interesting simply because men and women may react differently to lottery wins. On the other hand, analysis by age group will help to determine whether an increase in unearned income potentially leads to a significant change in people's personality traits even among the middle-aged. 
The results in Table 8 show that the size of the lottery win is positively and statistically significantly associated with extraversion for men and not women when OLS is used to estimate the equations. On the other hand, neuroticism is found to be associated negatively and statistically significantly at conventional levels with unearned income both for men and for women. Moreover, the estimated IV coefficient on $\ln L_{i t}$ is positive and statistically well determined at the 10 percent level in the agreeableness equation only for men. These results suggest that, on average, the size of the lottery win tends to have a much more robust effect on personality traits among men than women. However, it should be noted that the size of the coefficients does not appear to vary greatly across gender using the same specification.

With respect to age, Table 9 indicates that an increase in unearned income is strongly associated with extraversion (+ve) and neuroticism (-ve) for the under 40s when OLS is the preferred estimator. For people aged 40 and over, the size of the lottery win is found to be associated negatively and statistically significantly with neuroticism, and is positively associated with both agreeableness and conscientiousness. The positive and statistically important effect of unearned income on conscientiousness is new; it appears that an increase in unearned income leads individuals to become much more self-disciplined and careful with how they lead their life. Its marginal effect is also sizeable: A 1 percent increase in the lottery win is associated with an 11 percent increase (in standard deviation) in conscientiousness for this age group. More generally, however, the results on the 40-and-over age group do not support the claim by psychologists that personality traits reach maturity at the age of 30 and then remain fixed over the lifecycle (McCrae \& Costa, 1999).

Table 10 presents, as a check, OLS regressions on the effect of lottery win on the Big Five personality traits using the 2005 German Socio-Economic Panel (GSEOP). This comprises people who won at least $€ 500$ in the national lottery; hence the sample size is very small. Assuming that OLS will still produce consistent estimates for the effect of lottery win on extraversion, neuroticism, and openness, we can see that qualitatively similar results as those acquired via the BHPS are obtained in the German data set. An increase in the size of the lottery win is associated positively and statistically significantly with extraversion, while neuroticism is negatively and statistically significantly correlated with an increase in unearned income. Unfortunately, because of the very small sample size of lottery winners in the GSEOP, we are unable to replicate our findings using the same IV approach we adopted 
for the BHPS to tackle the endogeneity problems found in the agreeableness and conscientiousness equations.

\section{IV.Discussion}

One concern is that measures of noncognitive skills such as the Big Five personality traits are subjective and therefore do not have the required property of interpersonal comparability for them to be used as dependent variables in an economic model (Bertrand \& Mullainathan, 2001). In other words, we may have a problem if the measurement error associated with the collection of the Big Five personality traits also correlates with our explanatory variables of interest, which in the current article is the size of lottery win. This is a difficult question to answer, given that it is beyond our capacity to test whether winning larger prizes compared to winning smaller prizes affects in a causal manner the way that people self-report their personality traits. Nevertheless, we can attempt to address the question of the average measurement error of the Big Five personality variables. Though far from perfect, the 50-year history of their use and measurement within psychology suggests that self-reported data on personality traits are at least meaningful and valid on average. For example, identification of the Big Five traits was based on self-ratings of every personality-relevant word in the dictionaries of several languages, for which the same five traits consistently emerged through factor analysis, suggesting the universality of these traits (Goldberg, 1993; McCrae \& Costa, 1997). Second, there is high convergence between self- and peer-ratings, suggesting that the Big Five responses of people correspond with how others describe them (McCrae \& Costa, 1987). Moreover, there are robust associations between personality self-ratings and objective biological functioning (O’Cleirigh et al., 2007) as well as neural correlates of personality responses corresponding to a theoretical basis of the traits (Matthews \& Gilliland, 1999). Finally, self-ratings on each of the Big Five have also been found to strongly predict a huge range of objective occupational, social, and health behaviors (see, e.g., Hogan \& Holland, 2003; Hogan, 2005). However, more research is needed to determine the extent to which the reporting of personality traits can be affected by various life events throughout the lifecycle. With this in mind, readers are encouraged to consider our results with care.

A second concern is the objection is that the population of lottery winners is not necessarily representative of the UK population, which implies that our estimates may be considered as the local average treatment effects (LATE) rather than the average treatment 
effects (ATE) of income on personality traits. However, considering that a significant fraction, i.e., 50 percent, of the British population regularly participate in the national lottery (Wardle et al., 2007) and that wins are randomized across this sample, then the LATE from lottery wins on personality traits should approach the ATE (for an analogous example of the proximity of estimated LATE to ATE, see Oreopoulos, 2006). The same argument, however, may not apply in our German data set.

The third caveat that should be kept in mind is that only one period of personality variables are observed in the BHPS. Hence, we could treat our estimates as causal only if the dependent variable is strictly interpersonally comparable across the entire sample so that comparing the values at cross section is virtually the same as comparing the values within persons over time. While we may be able to say that the personality measures are valid and interpersonally comparable on average, with only cross-section data we are, at best, making inferences about the "perceived" rather than the "actual" causal effect of unearned income on noncognitive skills. In order to draw close to estimating the actual causal effect, a panel data set is required that contains repeated observations on personality traits and lottery wins. Unfortunately, data sets with the above qualities are rare and, wherever they exist, too imperfect to extract the actual causal effect of unearned income on personality traits. ${ }^{6}$

The fourth caveat, which is related to the third, is that the effect of unearned income on personality traits is temporary rather than permanent. It may be that people revert to the personality with which they started when they first entered adulthood. Again, without a longitudinal data set containing more than two periods of observations on personality, it is impossible for us to conclude either way. Researchers will need to return to this issue when new data sets become available.

One important question that arises from our findings concerns the mechanisms of the effects we observe. What explains why unearned incomes should affect measures of noncognitive characteristics in the way that they do? One plausible explanation is that an exogenous increase in income not only improves a person's capacity to spend but also his or her social status. Since there is strong evidence that people care tremendously about their relative income and income rank within a given social grouping (e.g., Clark \& Oswald, 1996;

\footnotetext{
${ }^{6}$ A potential candidate for such a data set is the German Panel (GSEOP) which was used in this paper's analysis. However, the personality traits variables are not measured on a year-to-year basis, i.e., there is a 4-year gap in between. Moreover, the lottery prize is truncated to EURO500+ win only and does not appear in every survey wave.
} 
Boyce et al., 2010b; Wood et al., in press), it is plausible that an improvement in status whether perceived or actual - will also raise their self-esteem and self-confidence, which are also highly correlated with the Big Five personality traits. For instance, individuals with high self-esteem - as measured by a survey question for individuals to report on a 5-point Likert scale on whether they see themselves as someone who has high self-esteem - tend to be more emotionally stable, extraverted, and conscientious, and to a lesser degree agreeable and open to experience (Robins et al., 2001). The link may also be causal: A highly self-esteemed individual may possess the self-confidence to engage in a wide range of social behaviors and, consequently, becomes more extraverted. However, there may be other routes with which unearned incomes can also influence our noncognitive traits. Yet it can be concluded that the directions of the effects of unearned income on personality traits are not surprising and are in line with previous findings in psychology.

Another key question is whether there is a wider implication of our findings that stretches beyond our suggestion that there may after all be scope for later intervention to improve the personality traits of adults. The first potential implication of our results concerns the common underlying assumption within economics that personality traits are seen as fixed and, in econometric equations where these so-called unobserved time-invariant factors are assumed to correlate with the right-hand-side variables, can be safely removed using fixedeffects estimators (see, e.g., Frijters \& Ferrer-i-Carbonell, 2004). However, our results suggest that fixed-effects estimators will correct for the unobserved relationship between the fixed components of personality and the explanatory variables of interest, but not the timevarying components of personality that also correlate with the right-hand-side variables. In addition, our results highlight the importance of unearned income on subjective well-being in general, because increasing unearned income helps to reduce neuroticism, which is an important trait predicting anxiety and depression, and helps to enhance extraversion, which is a key trait that predicts happiness and a general sense of well-being.

\section{Conclusion}

The current article investigates whether measures of noncognitive skills - i.e., personality traits that are weakly correlated with intelligence - can be influenced by changes in the unearned income experienced in adulthood. In doing so, we exploit the random assignment of medium-sized lottery wins to estimate the effect of unearned income on measures of the Big 
Five personality traits, namely one's levels of agreeableness, extraversion, conscientiousness, neuroticism, and openness. After correcting for the potential endogeneity bias in the lottery win variable, we find that over the range of unearned income between $£ 1$ and $£ 185,000$ (or between $\$ 1.50$ and $\$ 280,000$ ) the marginal effects of unearned income on agreeableness and extraversion are positive and statistically significant at the 5 percent level, and account for around 11 percent and 5 percent of standard deviation in the measures of agreeableness and extraversion respectively. On the other hand, we also find that the marginal effect of unearned income on neuroticism is negative and statistically significant at the 5 percent level; a 1 percent increase in lottery win is associated with a reduction of around 7 percent of standard deviation in neuroticism. The effects are much more precisely estimated for men than for women (although the size of the coefficients does not appear to vary greatly across gender). We also find that the effects vary with age but nevertheless continue to be statistically important among those aged 40 or above. Finally, we show that the qualitative conclusions obtained using the British data can be replicated for the German data set.

Overall, the data do not appear to support the idea that noncognitive traits "set like plaster" and cannot therefore be significantly altered as a result of changes in life events or social environment experienced by the individuals during adulthood. Our results call for a revision in the standard conceptual apparatus among policymakers and economists who tend to believe that virtually no scope can be made for later interventions to improve the personality traits of adults. Nevertheless, little is currently known about the underlying mechanisms with which noncognitive abilities can be affected by various experiences. For example, if the effects of unearned income on personality traits work only through the effects that improved relative ranking rather than absolute improvement in income have on personality, then a policy that awards all workers with the same amount of non-performancerelated bonus should have no impact whatsoever on employees' personality traits. For this reason, significantly more research into uncovering the underlying mechanisms that link experiences and noncognitive skills is required before any definite policy recommendations can be drawn. 


\section{References}

Agronick, Gail S.; and Duncan, Lauren E. 1998. Personality and social change: individual differences, life path, and importance attributed to women's movement. Journal of Personality and Social Psychology, 74, 1545-1555.

Apouey, Benedict; and Clark, Andrew E. 2009. Winning big but feeling no better? The effect of lottery prizes on physical and mental health. Paris School of Economics, mimeo.

Barrick, Murray R.; and Mount, Michael K. 1991. The big five personality dimensions and job performance: A meta-analysis. Personnel Psychology, 44, 1-26.

Bertrand, Marianne; and Mullainathan, Sendhil. 2001. Do people mean what they say? Implications for subjective survey data. American Economic Review, 91, 67-72.

Borghans, Lex; Duckworth, Angela L.; Heckman, James J., ter Weel, Bas. 2008. The economics and psychology of personality traits. Journal of Human Resources, 43, 972-1059.

Bowles, Samuel; Gintis, Herbert; and Osborne, Melissa. 2001a. Incentive-enhancing preferences: Personality behaviour and earning. American Economic Review, 91, 155-158.

Bowles, Samuel; Gintis, Herbert; and Osborne, Melissa. 2001b. The determinants of earnings: A behavioural approach. Journal of Economic Literature, 39, 1137-1176.

Boyce, Christopher J.; and Wood, Alex M. 2011a. Personality and the marginal utility of income: Personality interacts with increases in household income to determine life satisfaction. Journal of Economic Behavior \& Organization, 78, 183-191.

Boyce, Christopher J.; and Wood, Alex M. 2011b. Personality prior to disability determines adaptation: Agreeable individuals recover lost life satisfaction faster and more completely. Psychological Science, 22, 1397-1402. 
Boyce, Christopher J.; Wood, Alex M.; and Brown, Gordon D. A. 2010a. The dark side of conscientiousness: Conscientious people experience greater drops in life satisfaction following unemployment. Journal of Research in Personality, 44, 535-539.

Boyce, Christopher J.; Brown, Gordon D. A., \& Moore, Simon C. 2010b. Money and happiness: Rank of income, not income, affects life satisfaction. Psychological Science, 21, 471-475.

Brunello, Giorgio; and Schlotter, Martin. 2011. Non cognitive skills and personality traits: labour market relevance and their development and training system. IZA Discussion Paper \#5743.

Caneiro, Pedro M.; and Heckman, James J. 2003. Human capital policy. NBER Working Paper \#9495.

Clark, Andrew E.; Etile, Fabrice; Postel-Vinay, Fabian; Senik, Claudia; and Van der Straeten, Karine. 2005. Heterogeneity in reported well-being: Evidence from twelve European countries. Economic Journal, 115, 118-132.

Clark, Andrew E.; and Oswald, Andrew J. 1996. Satisfaction and comparison income. Journal of Public Economics, 61, 359-381.

Cunha, Flavio; and Heckman, James J. 2007. The technology of skill formation. American Economic Review, 97, 31-47.

Frijters, Paul; and Ferrer-i-Carbonell, Ada. 2004. How important is methodology for the estimates of the determinants of happiness?, Economic Journal, 114, 641-659. 
Frijters, Paul; Haisken-DeNew, John P.; and Shields, Michael A. 2004. Money does matter! Evidence from increasing real income and life satisfaction in East Germany following reunification. American Economic Review, 94, 730-740.

Gardner, Jonathan; and Oswald, Andrew J. 2007. Money and mental well-being: a longitudinal study of medium-sized lottery wins. Journal of Health Economics, 26, 49-60.

Georgellis, Yannis; Sessions, John G.; and Tsitsianis, Nikolaos. 2008. Social capital and windfalls: empirical evidence. Economics Letters, 99 (3), pp. 521-525.

Goldberg, Lewis R. 1993. The structure of phenotypic personality-traits. American Psychologist, 48(1), 26-34.

Groves, Melissa O. 2005. How important is your personality? Labor market returns to personality for women in the US and UK. Journal of Economic Psychology, 26, 827-841. Haan, Norma; Millsap, Roger; and Hartka, Elizabeth. 1986. As time goes by: change and stability in personality over fifty years. Psychology and Ageing, 1, 220-232.

Heckman, James J.; Stixrud, Jora.; and Urzua, Sergio. 2006. The effects of cognitive and non-cognitive skills on human capital and social behaviours. Journal of Labor Economics, 24, 411-482.

Heineck, Guido. 2011. Does it pay to be nice? Personality and earnings in the United Kingdom. Industrial and Labor Relations Review, 64, Article 9.

Hogan, Robert. 1996. A socioanalytic perspective on the five-factor model. In Jerry S. Wiggins (Ed.), The five-factor model of personality: theoretical perspectives (pp.180-207). New York: Guildford Press. 
Hogan, Robert. 2005. In defense of personality measurement: New wine for old whiners. Human Performance, 18, 331-41.

Hogan, Joynce; and Holland, Brent. 2003. Using theory to evaluate personality and jobperformance relations: A socioanalytic perspective. Journal of Applied Psychology, 88, 10012.

Imbens, Guido W.; Rubin, Donald B.; and Sacerdote, Bruce I. 2001. Estimating the effect of unearned income on labor earnings, savings, and consumption: Evidence from a survey of lottery players. American Economic Review, 91, 778-794.

Lindahl, Mikael. 2005. Estimating the effect of income on health and mortality using lottery prizes as an exogenous source of variation in income. Journal of Human Resources, 40, 144168.

Luttmer, Erzo. 2005. Neighbors as negatives: Relative earnings and well-being. Quarterly Journal of Economics, 120, 963-1003.

Matthews, Gerald; and Gilliland, Kirby. 1999. The personality theories of H. J. Eysenck and J. A. Gray: A comparative review. Personality and Individual Differences, 26, 583-626

McCrae, Robert R.; and Costa, Paul T. 1987. Validation of the 5-factor model of personality across instruments and observers. Journal of Personality and Social Psychology, 52, 81-90.

McCrae, Robert R. and Paul T. Costa. 1997. Personality trait structure as a human universal. American Psychologist, 52, 509-16.

McCrae, Robert R., Costa, Paul T. 1999. A five-factor theory of personality. In Lawrence A. Pervin \& Oliver P. John (Eds.), Handbook of personality and research ( $2^{\text {nd }}$ edition, pp.139153). New York: Guildford Press.

Nyhus, Ellen K.; and Pons, Empar. 2005. The effects of personality on earnings. Journal of Economic Psychology, 26, 363-384. 
O'Cleirigh, Conall; Ironson, Gail; Weiss; Alexander; and Costa, Paul T. 2007.

Conscientiousness predicts disease progression (Cd4 number and viral load) in people living with HIV. Health Psychology, 26, 473-80

Penner, Louis A.; Fritzsche, Brabara A.; Craiger, J Philip; and Freifeld, Tamara R. 1995. Measuring the prosocial personality. In Advances in Personality Assessment. Volume 10, ed. J Butcher, CD Spielberger,

Powdthavee, Nattavudh. 2009. I can't smile without you: spousal correlation in life satisfaction. Journal of Economic Psychology, 30(4), 675-689.

Powdthavee, Nattavudh. 2010. How much does money really matter? Estimating the causal effect of income on happiness. Empirical Economics, 39, 77-92.

Roberts, Brent W.; Walton, Kate E.; and Viechtbauer, Wolfgang. 2006. Patterns of meanlevel change in personality traits across the life course: A meta-analysis of longitudinal studies. Psychological Bulletin, 132, 1-25.

Robins, Richard W.; Tracy, Jessica L.; Trzesniewski; Kali H., Potter, Jeff; and Gosling, Samuel D. 2001. Personality correlates of self-esteem. Journal of Research in Personality, $35,463-482$.

Sacerdote, Bruce. 1996. The lottery winner survey, crime and social interactions, and why is there more crime in cities. $\mathrm{PhD}$ dissertation, Harvard University.

Salgado, Jesus F. 1997. The five factor model of personality and job performance in the European community. Journal of Applied Psychology, 82, 30-43.

Semykina, Anastasia; and Linz, Susan J. 2007. Gender differences in personality and earnings: Evidence from Russia. Journal of Economic Psychology, 28, 387-410.

Specht, Jule; Egloff, Boris; and Schmukle, Stefan C. 2011. Stability and change of personality across the life course: The impact of age and major life events on mean-level and 
rank-order stability of the Big Five. Journal of Personality and Social Psychology, 101(4), $862-882$.

Srivastava, Sanjay; John, Oliver P., Gosling, Samuel D., and Potter, Jeff. 2003. Development of personality in early and middle adulthood: set like plaster or persistent change? Journal of Personality and Social Psychology, 84, 1041-1053.

Taylor, M. F., Brice, J., Buck, N., Prentice-Lane, E., 2002. British Household Panel Survey User Manual. Colchester: University of Essex.

Walker, Ian. 1998. Lotteries: Determinants of ticket sales and optimal payout rate. Economic Policy, 27, 358-399.

Wardle, Heather; Sproston, Kerry; Orford, Jim; Erens, Bob; Griffiths, Mark; Constantine, Rebecca; and Pigott, Sarah, 2007. British Gambling Prevalence Survey 2007, National Centre for Social Research.

Winkelmann, Lilianna, and Winkelmann, Rainer. 2008. Personality, work, and satisfaction: Evidence from the German Socio-Economic Panel. The Journal of Positive Psychology, 3(4), 266-275

Wood, Alex M.; Boyce, Christopher, J.; Moore, Simon C.; and Brown, Gordon D.A. In press. An evolutionary based social rank explanation of why low income predicts mental distress: A 17 year cohort study of 30,000 people. Journal of Affective Disorder. 
Table I: Descriptive statistics: BHPS 2005

\begin{tabular}{lcccc}
\hline & & & $\mathbf{£ 1 0 1 -}$ & $\mathbf{f 5 0 +}$ \\
\hline Standardized personality variables & All & $\mathbf{£ 1 - £ 1 0 0}$ & $\mathbf{1 4 9 9}$ & $\mathbf{£ 5 0 +}$ \\
Agreeableness & -0.051 & -0.022 & -0.170 & 0.001 \\
& $(0.942)$ & $(0.947)$ & $(0.951)$ & $(0.856)$ \\
Extraversion & 0.096 & 0.041 & 0.166 & 0.415 \\
& $(0.997)$ & $(1.021)$ & $(0.915)$ & $(0.918)$ \\
Conscientiousness & 0.052 & 0.074 & 0.007 & -0.036 \\
& $(0.915)$ & $(0.914)$ & $(0.880)$ & $(1.019)$ \\
Neuroticism & -0.104 & -0.044 & -0.199 & -0.405 \\
& $(0.948)$ & $(0.961)$ & $(0.897)$ & $(0.887)$ \\
Openness & 0.099 & 0.078 & 0.191 & 0.041 \\
& $(0.929)$ & $(0.939)$ & $(0.916)$ & $(0.856)$ \\
ln(lottery win at $t)$ & 3.812 & 3.049 & 5.186 & 7.227 \\
& $(1.516)$ & $(0.830)$ & $(0.538)$ & $(0.754)$ \\
Lottery win at $t-1$ & 86.232 & 24.855 & 119.784 & 700.471 \\
& $(626.931)$ & $(102.425)$ & $(216.362)$ & $(2237.267)$ \\
Male & 0.582 & 0.549 & 0.674 & 0.642 \\
& $(0.493)$ & $(0.497)$ & $(0.469)$ & $(0.482)$ \\
Age & 45.255 & 46.264 & 43.004 & 41.904 \\
& $(17.527)$ & $(17.675)$ & $(17.943)$ & $(13.797)$ \\
\hline$N$ & & & & \\
\hline
\end{tabular}


Figure I: Distribution of lottery wins, BHPS 2005

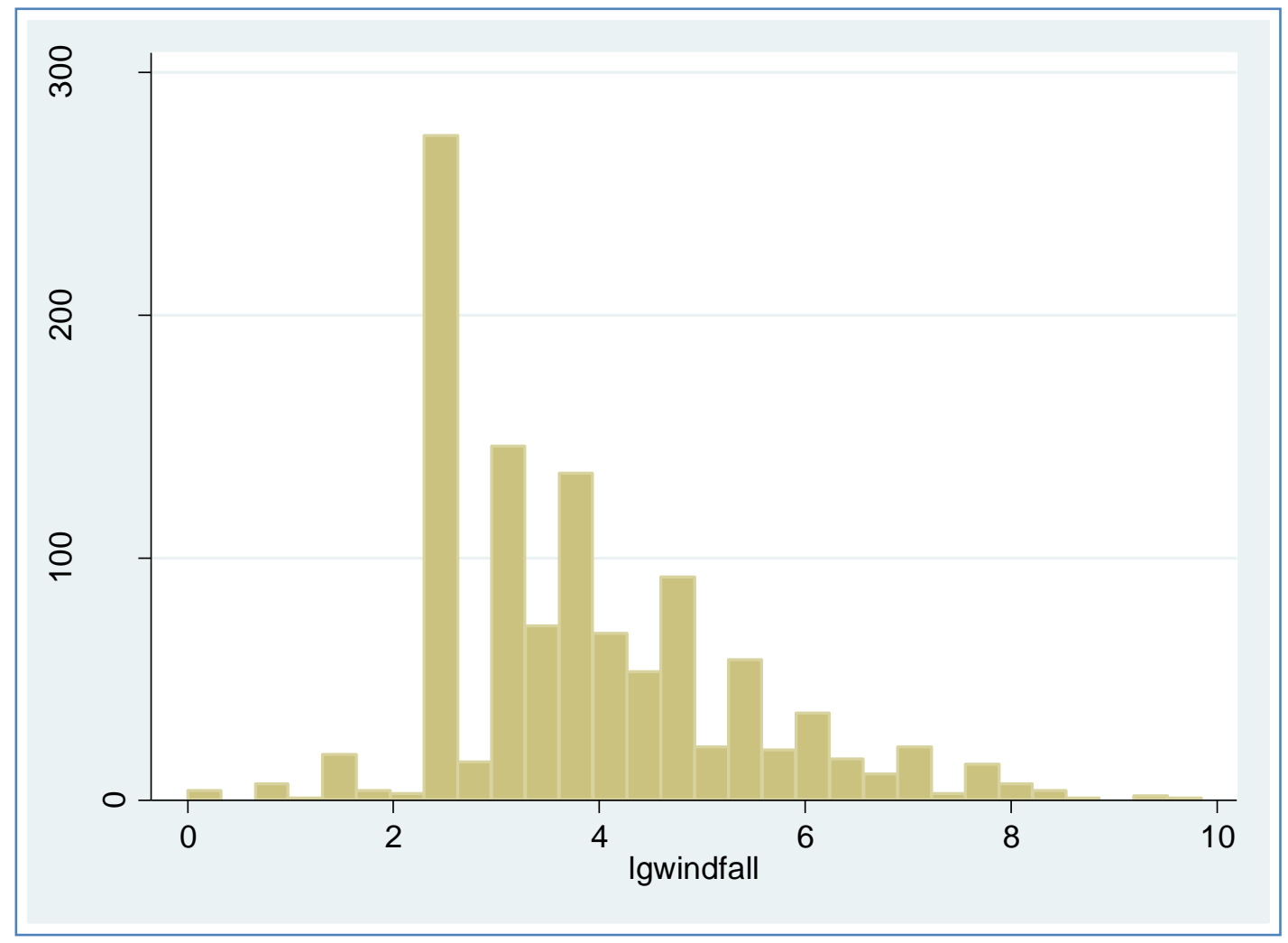


Table II: Predicting future lottery wins with current personality traits and lottery wins: BHPS 2005

\begin{tabular}{|c|c|c|c|c|}
\hline \multirow[b]{2}{*}{ VARIABLES } & \multicolumn{2}{|c|}{ Ln(lottery win at $t+1)$} & \multicolumn{2}{|c|}{$\begin{array}{c}\text { Ln(real personal income at } \\
t+1)\end{array}$} \\
\hline & (1) & (2) & (3) & (4) \\
\hline \multicolumn{5}{|l|}{ Standardized personality traits } \\
\hline \multirow[t]{2}{*}{ Agreeableness at $t$} & 0.000581 & -0.0251 & $-0.0712 * * *$ & -0.0135 \\
\hline & {$[0.0602]$} & {$[0.0566]$} & {$[0.0102]$} & {$[0.00890]$} \\
\hline \multirow[t]{2}{*}{ Extraversion at $t$} & 0.0725 & 0.0431 & 0.00847 & 0.0121 \\
\hline & {$[0.0559]$} & {$[0.0529]$} & {$[0.00968]$} & {$[0.00820]$} \\
\hline \multirow[t]{2}{*}{ Conscientiousness at $t$} & -0.0468 & -0.0249 & $0.0549 * * *$ & $0.0290 * * *$ \\
\hline & {$[0.0645]$} & {$[0.0620]$} & {$[0.0102]$} & {$[0.00879]$} \\
\hline \multirow[t]{2}{*}{ Neuroticism at $t$} & $-0.117 * *$ & -0.0851 & $-0.0430 * * *$ & -0.00496 \\
\hline & {$[0.0562]$} & {$[0.0544]$} & {$[0.00893]$} & {$[0.00757]$} \\
\hline \multirow[t]{2}{*}{ Openness at $t$} & -0.0306 & -0.0123 & $0.0385 * * *$ & $-0.0193 * *$ \\
\hline & {$[0.0596]$} & {$[0.0569]$} & {$[0.00928]$} & {$[0.00823]$} \\
\hline \multirow[t]{2}{*}{ Lottery win at $t$} & & $0.00130 * * *$ & & \\
\hline & & {$[0.000251]$} & & \\
\hline \multirow[t]{2}{*}{ Lottery win squared at $t$} & & $-6.05 \mathrm{e}-08 * * *$ & & \\
\hline & & {$[1.56 \mathrm{e}-08]$} & & \\
\hline \multirow[t]{2}{*}{ Real personal income at $t$} & & & & $5.46 \mathrm{e}-05^{* * *}$ \\
\hline & & & & {$[2.32 \mathrm{e}-06]$} \\
\hline \multirow[t]{2}{*}{ Real personal income squared at $t$} & & & & $-6.71 \mathrm{e}-11 * * *$ \\
\hline & & & & [7.87e-12] \\
\hline \multirow[t]{2}{*}{ Male } & 0.0691 & 0.000969 & $0.419 * * *$ & $0.113 * * *$ \\
\hline & [0.112] & {$[0.108]$} & {$[0.0187]$} & {$[0.0193]$} \\
\hline \multirow[t]{2}{*}{ Age } & 0.0121 & 0.00902 & $0.0716^{* * *}$ & $0.0356 * * *$ \\
\hline & {$[0.0154]$} & {$[0.0149]$} & {$[0.00319]$} & {$[0.00349]$} \\
\hline \multirow[t]{2}{*}{ Age-squared } & -0.000253 & -0.000200 & $-0.000716^{* * *}$ & $-0.000319 * * *$ \\
\hline & {$[0.000161]$} & {$[0.000155]$} & [2.99e-05] & [3.36e-05] \\
\hline \multirow[t]{2}{*}{ Constant } & $3.763 * * *$ & $3.717 * * *$ & $7.473 * * *$ & $7.530 * * *$ \\
\hline & {$[0.351]$} & {$[0.341]$} & {$[0.0769]$} & {$[0.0702]$} \\
\hline Observations & 926 & 926 & 12,115 & 12,115 \\
\hline R-squared & 0.029 & 0.114 & 0.122 & 0.428 \\
\hline
\end{tabular}

Note: $* *<5 \%$; $* * *<1 \%$. All independent variables are measured at time $t$ unless otherwise stated. Standard errors are in parentheses. 
Table III: Personality regressions with current and past lottery win as explanatory variables: BHPS 2005

\begin{tabular}{|c|c|c|c|c|c|}
\hline VARIABLES & $\begin{array}{c}(1) \\
\text { Agreeableness } \\
\end{array}$ & $\begin{array}{c}(2) \\
\text { Extraversion }\end{array}$ & $\begin{array}{c}(3) \\
\text { Conscientiousness } \\
\end{array}$ & $\begin{array}{c}(4) \\
\text { Neuroticism } \\
\end{array}$ & $\begin{array}{c}(5) \\
\text { Openness } \\
\end{array}$ \\
\hline $\operatorname{Ln}($ lottery win at $t)$ & $\begin{array}{l}-0.0121 \\
{[0.0195]}\end{array}$ & $\begin{array}{l}0.0530 * * \\
{[0.0206]}\end{array}$ & $\begin{array}{l}-0.0270 \\
{[0.0202]}\end{array}$ & $\begin{array}{c}-0.0616 * * * \\
{[0.0201]}\end{array}$ & $\begin{array}{c}-0.000375 \\
{[0.0192]}\end{array}$ \\
\hline Lottery win at $t-1$ & $\begin{array}{l}0.000190^{*} \\
{[0.000100]}\end{array}$ & $\begin{array}{c}-3.16 \mathrm{e}-05 \\
{[0.000120]}\end{array}$ & $\begin{array}{c}0.000114 \\
{[9.04 \mathrm{e}-05]}\end{array}$ & $\begin{array}{l}-5.47 \mathrm{e}-05 \\
{[0.000111]}\end{array}$ & $\begin{array}{c}1.27 \mathrm{e}-05 \\
{[0.000128]}\end{array}$ \\
\hline Lottery win squared at $t-1$ & $\begin{array}{l}-7.77 e-09 \\
{[6.93 e-09]}\end{array}$ & $\begin{array}{c}3.68 \mathrm{e}-09 \\
{[8.36 \mathrm{e}-09]}\end{array}$ & $\begin{array}{c}-2.03 e-09 \\
{[6.35 e-09]}\end{array}$ & $\begin{array}{c}8.01 \mathrm{e}-10 \\
{[7.26 \mathrm{e}-09]}\end{array}$ & $\begin{array}{c}0.000 \\
{[9.14 \mathrm{e}-09]}\end{array}$ \\
\hline Male & $\begin{array}{c}-0.350 * * * \\
{[0.0574]}\end{array}$ & $\begin{array}{c}-0.190 * * * \\
{[0.0618]}\end{array}$ & $\begin{array}{c}-0.186 * * * \\
{[0.0565]}\end{array}$ & $\begin{array}{c}-0.410^{* * * *} \\
{[0.0579]}\end{array}$ & $\begin{array}{c}0.110^{*} \\
{[0.0589]}\end{array}$ \\
\hline Age & $\begin{array}{l}0.0226 * * \\
{[0.00895]}\end{array}$ & $\begin{array}{c}-0.0292 * * * \\
{[0.00903]}\end{array}$ & $\begin{array}{c}0.0396 * * * \\
{[0.00874]}\end{array}$ & $\begin{array}{c}0.00860 \\
{[0.00861]}\end{array}$ & $\begin{array}{c}-0.00108 \\
{[0.00824]}\end{array}$ \\
\hline Age-squared & $\begin{array}{c}-0.000186 * * \\
{[9.24 \mathrm{e}-05]}\end{array}$ & $\begin{array}{l}0.000185^{*} \\
{[9.51 \mathrm{e}-05]}\end{array}$ & $\begin{array}{c}-0.000383 * * * \\
{[9.24 \mathrm{e}-05]}\end{array}$ & $\begin{array}{l}-0.000138 \\
{[8.85 \mathrm{e}-05]}\end{array}$ & $\begin{array}{l}-8.93 \mathrm{e}-05 \\
{[8.65 \mathrm{e}-05]}\end{array}$ \\
\hline Constant & $\begin{array}{c}-0.404^{*} \\
{[0.215]}\end{array}$ & $\begin{array}{c}0.895 * * * \\
{[0.211]}\end{array}$ & $\begin{array}{c}-0.644 * * * \\
{[0.207]}\end{array}$ & $\begin{array}{c}0.306 \\
{[0.210]}\end{array}$ & $\begin{array}{c}0.283 \\
{[0.193]}\end{array}$ \\
\hline $\begin{array}{l}\text { Observations } \\
\text { R-squared }\end{array}$ & $\begin{array}{l}1,050 \\
0.053\end{array}$ & $\begin{array}{l}1,049 \\
0.054\end{array}$ & $\begin{array}{l}1,048 \\
0.039\end{array}$ & $\begin{array}{l}1,053 \\
0.067\end{array}$ & $\begin{array}{l}1,050 \\
0.039\end{array}$ \\
\hline
\end{tabular}

Note: $*<10 \% ; * *<5 \% ; * * *<1 \%$. The dependent variables are standardized personality variables $\sim \mathrm{N}(0,1)$. Standard errors are in parentheses. 
Table IV: Hausman test for endogeneity: BHPS 2005

\begin{tabular}{|c|c|c|c|c|c|}
\hline VARIABLES & $\begin{array}{c}(1) \\
\text { Agreeableness }\end{array}$ & $\begin{array}{c}(2) \\
\text { Extraversion }\end{array}$ & $\begin{array}{c}\text { (3) } \\
\text { Conscientiousness }\end{array}$ & $\begin{array}{c}\text { (4) } \\
\text { Neuroticism }\end{array}$ & $\begin{array}{c}\text { (5) } \\
\text { Openness }\end{array}$ \\
\hline $\operatorname{Ln}($ lottery win at $t)$ & $\begin{array}{c}0.206 * * * \\
{[0.0498]}\end{array}$ & $\begin{array}{c}0.0779 \\
{[0.0720]}\end{array}$ & $\begin{array}{c}0.171 * * * \\
{[0.0431]}\end{array}$ & $\begin{array}{c}-0.161 * * * \\
{[0.0589]}\end{array}$ & $\begin{array}{c}0.0276 \\
{[0.0519]}\end{array}$ \\
\hline$\hat{v}$ & $\begin{array}{c}-0.215^{* * *} * \\
{[0.0536]}\end{array}$ & $\begin{array}{c}-0.0265 \\
{[0.0752]}\end{array}$ & $\begin{array}{c}-0.197 * * * \\
{[0.0482]}\end{array}$ & $\begin{array}{c}0.0993 \\
{[0.0627]}\end{array}$ & $\begin{array}{l}-0.0280 \\
{[0.0540]}\end{array}$ \\
\hline Male & $\begin{array}{c}-0.388 * * * \\
{[0.0590]}\end{array}$ & $\begin{array}{c}-0.196 * * * \\
{[0.0636]}\end{array}$ & $\begin{array}{c}-0.222 * * * \\
{[0.0578]}\end{array}$ & $\begin{array}{c}-0.392 * * * \\
{[0.0594]}\end{array}$ & $\begin{array}{c}0.105^{*} \\
{[0.0611]}\end{array}$ \\
\hline Age & $\begin{array}{l}0.0206^{* *} \\
{[0.00900]}\end{array}$ & $\begin{array}{c}-0.0295 * * * \\
{[0.00907]}\end{array}$ & $\begin{array}{c}0.0378 * * * \\
{[0.00879]}\end{array}$ & $\begin{array}{c}0.00950 \\
{[0.00865]}\end{array}$ & $\begin{array}{c}-0.00133 \\
{[0.00830]}\end{array}$ \\
\hline Age-squared & $\begin{array}{c}-0.000161 * \\
{[9.30 \mathrm{e}-05]}\end{array}$ & $\begin{array}{c}0.000188^{* *} \\
{[9.57 \mathrm{e}-05]}\end{array}$ & $\begin{array}{c}-0.000360 * * * \\
{[9.29 \mathrm{e}-05]}\end{array}$ & $\begin{array}{c}-0.000150^{*} \\
{[8.90 \mathrm{e}-05]}\end{array}$ & $\begin{array}{l}-8.61 \mathrm{e}-05 \\
{[8.73 \mathrm{e}-05]}\end{array}$ \\
\hline Constant & $\begin{array}{c}-1.124 * * * \\
{[0.253]}\end{array}$ & $\begin{array}{c}0.811 * * * \\
{[0.304]}\end{array}$ & $\begin{array}{c}-1.299 * * * \\
{[0.228]}\end{array}$ & $\begin{array}{c}0.635^{* *} \\
{[0.272]}\end{array}$ & $\begin{array}{c}0.190 \\
{[0.231]}\end{array}$ \\
\hline $\begin{array}{l}\text { Observations } \\
\text { R-squared }\end{array}$ & $\begin{array}{l}1,050 \\
0.053\end{array}$ & $\begin{array}{l}1,049 \\
0.054\end{array}$ & $\begin{array}{l}1,048 \\
0.039\end{array}$ & $\begin{array}{l}1,053 \\
0.067\end{array}$ & $\begin{array}{l}1,050 \\
0.039\end{array}$ \\
\hline
\end{tabular}

Note: $*<10 \% ; * *<5 \% ; * * *<1 \%$. The dependent variables are standardized personality variables $\sim \mathrm{N}(0,1)$. Standard errors are in parentheses. 
Table V: First-stage regression equations for each personality trait: BHPS 2005

\begin{tabular}{|c|c|c|c|c|c|}
\hline & $\begin{array}{c}(1) \\
\text { Agreeableness }\end{array}$ & $\begin{array}{c}(2) \\
\text { Extraversion } \\
\end{array}$ & $\begin{array}{c}(3) \\
\text { Conscientiousness }\end{array}$ & $\begin{array}{c}(4) \\
\text { Neuroticism } \\
\end{array}$ & $\begin{array}{c}(5) \\
\text { Openness } \\
\end{array}$ \\
\hline VARIABLES & \multicolumn{5}{|c|}{ Dependent variable: $\ln ($ lottery win at $t)$} \\
\hline Lottery win at $t-1$ & $\begin{array}{l}0.00201 * * * \\
{[0.000350]}\end{array}$ & $\begin{array}{l}0.00201 * * * \\
{[0.000350]}\end{array}$ & $\begin{array}{l}0.00201 * * * \\
{[0.000350]}\end{array}$ & $\begin{array}{l}0.00201 * * * \\
{[0.000350]}\end{array}$ & $\begin{array}{l}0.00201 * * * \\
{[0.000350]}\end{array}$ \\
\hline Lottery squared at $t-1$ & $\begin{array}{c}-1.19 \mathrm{e}-07 * * * \\
{[2.47 \mathrm{e}-08]}\end{array}$ & $\begin{array}{c}-1.18 \mathrm{e}-07 * * * \\
{[2.47 \mathrm{e}-08]}\end{array}$ & $\begin{array}{c}-1.19 \mathrm{e}-07 * * * \\
{[2.47 \mathrm{e}-08]}\end{array}$ & $\begin{array}{c}-1.18 \mathrm{e}-07 * * * \\
{[2.47 \mathrm{e}-08]}\end{array}$ & $\begin{array}{c}-1.19 \mathrm{e}-07 * * * \\
{[2.47 \mathrm{e}-08]}\end{array}$ \\
\hline Male & $\begin{array}{c}0.212 * * \\
{[0.0883]}\end{array}$ & $\begin{array}{c}0.214 * * \\
{[0.0886]}\end{array}$ & $\begin{array}{c}0.205^{* *} \\
{[0.0884]}\end{array}$ & $\begin{array}{l}0.215^{* *} \\
{[0.0883]}\end{array}$ & $\begin{array}{l}0.212 * * \\
{[0.0883]}\end{array}$ \\
\hline Age & $\begin{array}{c}0.0143 \\
{[0.0130]}\end{array}$ & $\begin{array}{c}0.0118 \\
{[0.0131]}\end{array}$ & $\begin{array}{c}0.0142 \\
{[0.0130]}\end{array}$ & $\begin{array}{c}0.0128 \\
{[0.0130]}\end{array}$ & $\begin{array}{c}0.0143 \\
{[0.0130]}\end{array}$ \\
\hline Age-squared & $\begin{array}{l}-0.000226^{*} \\
{[0.000126]}\end{array}$ & $\begin{array}{l}-0.000195 \\
{[0.000127]}\end{array}$ & $\begin{array}{l}-0.000225^{*} \\
{[0.000125]}\end{array}$ & $\begin{array}{l}-0.000205 \\
{[0.000126]}\end{array}$ & $\begin{array}{l}-0.000226^{*} \\
{[0.000126]}\end{array}$ \\
\hline Constant & $\begin{array}{c}3.327 * * * \\
{[0.318]}\end{array}$ & $\begin{array}{c}3.375 * * * \\
{[0.320]}\end{array}$ & $\begin{array}{c}3.336^{* * * *} \\
{[0.318]}\end{array}$ & $\begin{array}{c}3.327 * * * \\
{[0.318]}\end{array}$ & $\begin{array}{c}3.327 * * * \\
{[0.318]}\end{array}$ \\
\hline $\begin{array}{l}\text { Partial R-squared of } \\
\text { excluded instruments: } \\
\text { F-test of excluded } \\
\text { instruments: } \\
\text { Hansen J statistic } \\
\text { (OVERID) }\end{array}$ & $\begin{array}{c}0.1173 \\
17.24[0.000]\end{array}$ & $\begin{array}{c}0.1162 \\
17.28[0.000]\end{array}$ & $\begin{array}{c}0.1172 \\
17.26[0.000]\end{array}$ & $\begin{array}{c}0.1162 \\
17.26[0.000]\end{array}$ & $\begin{array}{c}0.1149 \\
17.30[0.000]\end{array}$ \\
\hline Observations & 1,050 & 1,049 & 1,048 & 1,053 & 1,050 \\
\hline R-squared & 0.136 & 0.136 & 0.136 & 0.136 & 0.136 \\
\hline
\end{tabular}

Note: $*<10 \%$; $* *<5 \%$; $* * *<1 \%$. The dependent variable for each of the personality trait equations is the log of lottery win at $t$. Standard errors are in parentheses. P-values are reported for all tests. 
Table VI: OLS and IV personality traits regression equations: BHPS 2005

\begin{tabular}{|c|c|c|c|c|c|}
\hline VARIABLES & $\begin{array}{c}(1) \\
\text { Agreeableness }\end{array}$ & $\begin{array}{c}(2) \\
\text { Extraversion } \\
\end{array}$ & $\begin{array}{c}\text { (3) } \\
\text { Conscientiousness }\end{array}$ & $\begin{array}{c}(4) \\
\text { Neuroticism }\end{array}$ & $\begin{array}{c}\text { (5) } \\
\text { Openness }\end{array}$ \\
\hline \multicolumn{6}{|l|}{ i) OLS } \\
\hline $\operatorname{Ln}($ lottery win at $\mathrm{t})$ & $\begin{array}{c}0.00186 \\
{[0.0184]}\end{array}$ & $\begin{array}{c}0.0527 * * * \\
{[0.0193]}\end{array}$ & $\begin{array}{c}-0.0165 \\
{[0.0191]}\end{array}$ & $\begin{array}{c}-0.0668 * * * \\
{[0.0185]}\end{array}$ & $\begin{array}{r}0.000989 \\
{[0.0184]}\end{array}$ \\
\hline Observations & 1,050 & 1,049 & 1,048 & 1,053 & 1,050 \\
\hline R-squared & 0.049 & 0.054 & 0.035 & 0.067 & 0.039 \\
\hline \multicolumn{6}{|l|}{ ii) IV(a) } \\
\hline $\operatorname{Ln}($ lottery win at $\mathrm{t})$ & $\begin{array}{c}0.107 * * \\
{[0.0462]}\end{array}$ & $\begin{array}{c}0.0504 \\
{[0.0489]}\end{array}$ & $\begin{array}{c}0.0632 \\
{[0.0471]}\end{array}$ & $\begin{array}{c}-0.106^{* *} \\
{[0.0495]}\end{array}$ & $\begin{array}{c}0.0115 \\
{[0.0526]}\end{array}$ \\
\hline Observations & 1,050 & 1,049 & 1,048 & 1,053 & 1,050 \\
\hline R-squared & 0.021 & 0.054 & 0.018 & 0.063 & 0.039 \\
\hline \multicolumn{6}{|l|}{ iii) IV(b) } \\
\hline $\operatorname{Ln}($ lottery win at $\mathrm{t})$ & $\begin{array}{l}0.114 * * \\
{[0.0547]}\end{array}$ & $\begin{array}{c}0.0305 \\
{[0.0531]} \\
\end{array}$ & $\begin{array}{c}0.0529 \\
{[0.0438]}\end{array}$ & $\begin{array}{c}-0.0897 * \\
{[0.0494]} \\
\end{array}$ & $\begin{array}{l}-0.00606 \\
{[0.0512]} \\
\end{array}$ \\
\hline Observations & 1,050 & 1,049 & 1,048 & 1,053 & 1,050 \\
\hline R-squared & 0.040 & 0.083 & 0.059 & 0.170 & 0.115 \\
\hline
\end{tabular}

Note: $*<10 \% ; * *<5 \% ; * * *<1 \%$ IV(a) includes only age, age-squared, and gender as other excluded instruments. IV(b) add to (a) education, marital statuses, employment statuses, health, log of real personal income, and number of children as additional excluded instruments. Standard errors are in parentheses. 
Table VII: OLS and IV personality traits regression equations with a win of $£ 1000+:$ BHPS 2005

\begin{tabular}{|c|c|c|c|c|c|}
\hline VARIABLES & $\begin{array}{c}\text { (1) } \\
\text { Agreeableness }\end{array}$ & $\begin{array}{c}(2) \\
\text { Extraversion }\end{array}$ & $\begin{array}{c}\text { (3) } \\
\text { Conscientiousness }\end{array}$ & $\begin{array}{c}(4) \\
\text { Neuroticism }\end{array}$ & $\begin{array}{c}(5) \\
\text { Openness }\end{array}$ \\
\hline \multicolumn{6}{|l|}{ i) OLS } \\
\hline \multirow[t]{2}{*}{ Lottery win of $£ 1,000+$} & $0.303 * *$ & $0.378 * * *$ & -0.0913 & $-0.361 * *$ & 0.0223 \\
\hline & {$[0.134]$} & {$[0.143]$} & {$[0.153]$} & {$[0.143]$} & {$[0.137]$} \\
\hline Observations & 1,050 & 1,049 & 1,048 & 1,053 & 1,050 \\
\hline R-squared & 0.051 & 0.057 & 0.037 & 0.059 & 0.046 \\
\hline \multicolumn{6}{|l|}{ ii) IV } \\
\hline \multirow[t]{2}{*}{ Lottery win of $£ 1,000+$} & $0.862 * * *$ & 0.409 & $0.570 *$ & $-0.831^{* *}$ & 0.100 \\
\hline & {$[0.291]$} & {$[0.371]$} & {$[0.292]$} & {$[0.348]$} & {$[0.341]$} \\
\hline \multirow{2}{*}{$\begin{array}{l}\text { Endogeneity test: Hausman } \\
\text { coefficient }(v)\end{array}$} & $1200 * * *$ & 0136 & $1601 * * *$ & _0 957* & 0173 \\
\hline & [0.435] & {$[0.637]$} & {$[0.414]$} & [0.497] & [0.485] \\
\hline $\begin{array}{l}\text { Partial R-squared of excluded } \\
\text { instruments: }\end{array}$ & 0.1349 & 0.1349 & 0.1349 & 0.1349 & 0.1353 \\
\hline F-test of excluded instruments: & $83.24[0.000]$ & $83.25[0.000]$ & $83.17[0.000]$ & $83.31[0.000]$ & $80.69[0.000]$ \\
\hline Hansen J statistic (OVERID) & $0.536[0.4641]$ & $0.094[0.7587]$ & $2.212[0.1370]$ & $0.078[0.7801]$ & $0.050[0.8236]$ \\
\hline Observations & 1,050 & 1,049 & 1,048 & 1,053 & 1,050 \\
\hline R-squared & 0.040 & 0.053 & 0.017 & 0.052 & 0.039 \\
\hline
\end{tabular}

Note: $*<10 \% ; * *<5 \% ; * * *<1 \%$. Standard errors are in parentheses. P-values are reported for all tests. 
Table VIII: OLS and IV personality traits regression equations by gender: BHPS 2005

\begin{tabular}{|c|c|c|c|c|c|}
\hline VARIABLES & $\begin{array}{c}(1) \\
\text { Agreeableness }\end{array}$ & $\begin{array}{c}(2) \\
\text { Extraversion }\end{array}$ & $\begin{array}{c}\text { (3) } \\
\text { Conscientiousness }\end{array}$ & $\begin{array}{c}(4) \\
\text { Neuroticism }\end{array}$ & $\begin{array}{c}\text { (5) } \\
\text { Openness }\end{array}$ \\
\hline \multicolumn{6}{|l|}{ i) OLS, Men } \\
\hline $\operatorname{Ln}($ lottery win at $t)$ & $\begin{array}{l}0.00852 \\
{[0.0238]}\end{array}$ & $\begin{array}{c}0.0755^{* * * *} \\
{[0.0242]}\end{array}$ & $\begin{array}{l}-0.0113 \\
{[0.0243]}\end{array}$ & $\begin{array}{c}-0.0699 * * * \\
{[0.0226]}\end{array}$ & $\begin{array}{c}0.0202 \\
{[0.0216]}\end{array}$ \\
\hline Observations & 609 & 608 & 608 & 610 & 608 \\
\hline R-squared & 0.005 & 0.071 & 0.030 & 0.015 & 0.043 \\
\hline \multicolumn{6}{|l|}{ ii) IV, Men } \\
\hline $\operatorname{Ln}($ lottery win at $t)$ & $\begin{array}{l}0.0959^{*} \\
{[0.0542]}\end{array}$ & $\begin{array}{c}0.0581 \\
{[0.0555]}\end{array}$ & $\begin{array}{c}0.0709 \\
{[0.0536]}\end{array}$ & $\begin{array}{l}-0.115^{*} \\
{[0.0596]}\end{array}$ & $\begin{array}{c}0.0543 \\
{[0.0356]}\end{array}$ \\
\hline Observations & 609 & 608 & 608 & 610 & 608 \\
\hline R-squared & 0.015 & 0.070 & 0.010 & 0.009 & 0.040 \\
\hline \multicolumn{6}{|l|}{ ii) OLS, Women } \\
\hline $\operatorname{Ln}($ lottery win at $t)$ & $\begin{array}{l}-0.0147 \\
{[0.0292]}\end{array}$ & $\begin{array}{r}0.0151 \\
{[0.0321]} \\
\end{array}$ & $\begin{array}{l}-0.0221 \\
{[0.0312]}\end{array}$ & $\begin{array}{l}-0.0597 * \\
{[0.0318]} \\
\end{array}$ & $\begin{array}{c}-0.0334 \\
{[0.0333]} \\
\end{array}$ \\
\hline Observations & 441 & 441 & 440 & 443 & 442 \\
\hline R-squared & 0.037 & 0.031 & 0.016 & 0.034 & 0.029 \\
\hline $\begin{array}{l}\text { ii) IV, Women } \\
\text { Ln(lottery win at t) }\end{array}$ & $\begin{array}{c}0.0997 \\
{[0.0811]}\end{array}$ & $\begin{array}{l}0.0447 \\
{[0.103]}\end{array}$ & $\begin{array}{c}0.0353 \\
{[0.0800]}\end{array}$ & $\begin{array}{l}-0.0822 \\
{[0.0663]}\end{array}$ & $\begin{array}{c}0.00328 \\
{[0.152]}\end{array}$ \\
\hline Observations & 441 & 441 & 440 & 443 & 442 \\
\hline R-squared & 0.004 & 0.029 & 0.008 & 0.033 & 0.026 \\
\hline
\end{tabular}

Note: $*<10 \% ; * * *<1 \%$. IV includes only age, age-squared, and gender as other excluded instruments. 
Table IX: OLS and IV personality traits regression equations by age group: BHPS 2005

\begin{tabular}{|c|c|c|c|c|c|}
\hline VARIABLES & $\begin{array}{c}(1) \\
\text { Agreeableness }\end{array}$ & $\begin{array}{c}(2) \\
\text { Extraversion }\end{array}$ & $\begin{array}{c}\text { (3) } \\
\text { Conscientiousness }\end{array}$ & $\begin{array}{c}(4) \\
\text { Neuroticism }\end{array}$ & $\begin{array}{c}\text { (5) } \\
\text { Openness }\end{array}$ \\
\hline \multicolumn{6}{|l|}{ i) OLS, Age $<40$} \\
\hline $\operatorname{Ln}($ lottery win at $t)$ & $\begin{array}{c}0.0104 \\
{[0.0278]}\end{array}$ & $\begin{array}{c}0.0872 * * * \\
{[0.0277]}\end{array}$ & $\begin{array}{l}-0.0127 \\
{[0.0258]}\end{array}$ & $\begin{array}{c}-0.0769 * * * \\
{[0.0266]}\end{array}$ & $\begin{array}{l}-0.00655 \\
{[0.0266]}\end{array}$ \\
\hline Observations & 426 & 425 & 425 & 426 & 425 \\
\hline R-squared & 0.032 & 0.076 & 0.055 & 0.086 & 0.018 \\
\hline \multicolumn{6}{|l|}{ ii) IV, Age $<40$} \\
\hline $\operatorname{Ln}($ lottery win at $t)$ & $\begin{array}{l}-0.0133 \\
{[0.0737]}\end{array}$ & $\begin{array}{l}0.119 * * \\
{[0.0535]}\end{array}$ & $\begin{array}{l}0.00973 \\
{[0.0622]}\end{array}$ & $\begin{array}{l}-0.0267 \\
{[0.0518]}\end{array}$ & $\begin{array}{c}-0.0298 \\
{[0.0634]}\end{array}$ \\
\hline Observations & 426 & 425 & 425 & 426 & 425 \\
\hline R-squared & 0.030 & 0.073 & 0.053 & 0.079 & 0.016 \\
\hline \multicolumn{6}{|l|}{ ii) OLS, Age $>=40$} \\
\hline $\operatorname{Ln}($ lottery win at $t)$ & $\begin{array}{l}-0.00433 \\
{[0.0247]} \\
\end{array}$ & $\begin{array}{r}0.0302 \\
{[0.0269]} \\
\end{array}$ & $\begin{array}{l}-0.0196 \\
{[0.0280]}\end{array}$ & $\begin{array}{c}-0.0545^{* *} \\
{[0.0257]} \\
\end{array}$ & $\begin{array}{c}0.0112 \\
{[0.0258]}\end{array}$ \\
\hline Observations & 624 & 624 & 623 & 627 & 625 \\
\hline R-squared & 0.039 & 0.016 & 0.019 & 0.057 & 0.024 \\
\hline $\begin{array}{l}\text { ii) } \mathbf{I V}, \text { Age }>=\mathbf{4 0} \\
\operatorname{Ln}(\text { lottery win at t })\end{array}$ & $\begin{array}{l}0.136 * * \\
{[0.0557]}\end{array}$ & $\begin{array}{c}0.0387 \\
{[0.0644]}\end{array}$ & $\begin{array}{l}0.108 * * \\
{[0.0515]}\end{array}$ & $\begin{array}{l}-0.145 * * \\
{[0.0695]}\end{array}$ & $\begin{array}{c}0.0605 \\
{[0.0463]}\end{array}$ \\
\hline Observations & 624 & 624 & 623 & 627 & 625 \\
\hline R-squared & -0.008 & 0.016 & -0.018 & 0.039 & 0.019 \\
\hline
\end{tabular}

Note: $* *<5 \%$; $* * *<1 \%$. IV includes only age, age-squared, and gender as other excluded instruments. 
Table X: Personality regressions with lottery win (over $€ 500$ ): German Panel Data, GSEOP 2005

\begin{tabular}{lccccc}
\hline VARIABLES & $\begin{array}{c}(1) \\
\text { agreeableness }\end{array}$ & $\begin{array}{c}(2) \\
\text { extraversion }\end{array}$ & $\begin{array}{c}(3) \\
\text { conscientiousness }\end{array}$ & $\begin{array}{c}(4) \\
\text { neuroticism }\end{array}$ & $\begin{array}{c}(5) \\
\text { openness }\end{array}$ \\
\hline \multirow{3}{*}{ ln(lottery win) } & & & & & \\
& 0.142 & $0.265^{* * *}$ & 0.021 & $-0.178^{*}$ & 0.089 \\
Constant & {$[0.100]$} & {$[0.076]$} & {$[0.116]$} & {$[0.103]$} & {$[0.099]$} \\
& -1.317 & $-2.191^{* * *}$ & -0.330 & $1.645^{*}$ & -0.651 \\
& {$[0.830]$} & {$[0.695]$} & {$[0.951]$} & {$[0.818]$} & {$[0.814]$} \\
\hline Observations & 45 & 45 & 44 & 44 & 45 \\
R-squared & 0.046 & 0.163 & 0.001 & 0.069 & 0.020 \\
\hline
\end{tabular}

Note: $*<10 \% ; * * *<1 \%$. Sample contains only lottery winners. 